\title{
PENGEMBANGAN MODEL PEMBELAJARAN BERBASIS PERMAINAN TRADISIONAL UNTUK MENINGKATKAN KEMAMPUAN MOTORIK KASAR ANAK TUNAGRAHITA RINGAN
}

\section{DEVELOPING A TEACHING MODEL OF TRADITIONAL GAMES TO INCREASE GROSS MOTOR OF INTELLECTUAL DEVELOPMENTAL DISORDER CHILDREN}

\author{
Asep Ardiyanto, Pamuji Sukoco \\ SD Negeri Pokoh 2 Sleman Yogyakarta, Universitas Negeri Yogyakarta \\ ardiyanto.hernanda@gmail.com,pamujisukoco@yahoo.co.id
}

\begin{abstract}
Abstrak
Penelitian ini bertujuan untuk menghasilkan model pembelajaran berbasis permainan tradisional untuk meningkatkan kemampuan motorik kasar anak tunagrahita ringan yang layak digunakan. Penelitian pengembangan ini dilakukan dengan langkah-langkah sebagai berikut: (1) pengumpulan informasi, (2) analisis hasil informasi, (3) mengembangkan produk awal, (4) validasi ahli dan revisi, (5) uji coba skala kecil, (6) revisi, (7) uji coba skala besar, (8) revisi akhir, (9) pembuatan produk final, dan (10) diseminasi dan implementasi produk final. Uji coba skala kecil dilakukan terhadap 6 siswa tunagrahita ringan SLB Tunas Kasih 2 Turi. Uji coba skala besar dilakukan terhadap 12 siswa tunagrahita ringan SLB ABCD Tunas Kasih Donoharjo. Teknik analisis data yang digunakan yaitu deskriptif kuantitatif dan deskriptif kualitatif. Penelitian ini menghasilkan model pembelajaran, yaitu: (1) balap sarung, (2) lempar karet, (3) dorong ban, (4) engkling, (5) pukul balon, (6) layang-layang, (7) lompat tali, dan (8) pesawat terbang. Dari hasil analisis data penilaian para ahli materi dan guru SLB, ditarik kesimpulan bahwa pengembangan model pembelajaran ini sangat baik dan efektif.
\end{abstract}

Kata kunci: pengembangan, permainan tradisional, pembelajaran motorik kasar, anak tunagrahita ringan.

\begin{abstract}
The goal of this research is to produce a teaching model of traditional games to increase gross motor of intellectual developmental disorder children which can be used appropriately. This developmental research was done following developmental research steps as follows: (1) collecting information, (2) analysing information, (3) developing initial product, (4) experts validation and revision, (5) preliminary field testing, (6) revision, (7) main field testing, (8) final revision, (9) making the final product, and (10) dissemination and implementation the final product. The preliminary field testing was conducted to six students of SLB Tunas Kasih 2 Turi and the main field testing was conducted to 12 students of SLB ABCD Tunas Kasih Donoharjo. The data were analyzed using the quantitative descriptive analysis and qualitative descriptive analysis. This study resulted in a model a teaching that is: (1) glove racing, (2) rubber throwing, (3) belt thrusting, (4) hopscotch, (5) hitting balloon, (6) kite, (7) rope jumping, and (8) aircraft. Based on the data analysis derived from teachers and expert assessment, it is concluded that the model is considered as very satisfactory and effective.
\end{abstract}

Keywords: development, traditional games, gross motor teaching, intellectual developmental disorder children. 


\section{Pendahuluan}

Pendidikan yang bermutu dalam praktek proses pembelajaran harus dapat memenuhi seluruh kebutuhan peserta didik atau dengan kata lain proses pembelajaran berpusat pada peserta didik. Peserta didik harus merasa nyaman, senang dan tidak tertekan ketika terlibat dalam kegiatan belajar. Pembelajaran harus memberikan makna yang mendalam dan selalu diarahkan untuk tumbuh dan kembang peserta didik, menghargai lingkungan sehingga potensinya dapat berkembang secara optimal. Pendidikan yang bermutu secara fungsional menghantarkan setiap individu untuk mampu bertahan, berdaya saing, secara mandiri dalam kehidupan yang dinamis dan bergerak cepat penuh persaingan.

Di lain pihak praktik-praktik pendidikan khususnya layanan proses pembelajaran yang selama ini banyak dilakukan, baru sebatas pada bagaimana peserta didik dibelajarkan untuk menerima sejumlah materi guna memenuhi tuntutan program dan kurikulum yang telah ditetapkan, di mana program pembelajaran dirancang sesuai dengan jadwal untuk memenuhi target-target yang sarat dan ketat. Daya serap pembelajaran diukur melalui penilaian yang belum sepenuhnya mengukur kompetensi peserta didik.

Layanan pembelajaran belum banyak menyentuh kepentingan peserta didik sebagai pembelajar, layanan pembelajaran belum memenuhi kekhasan serta keberagaman peserta didik, yang berkaitan dengan kondisi fisik, kecerdasan, mental, emosional dan sosial. Padahal layanan pendidikan yang bermutu telah menjadi komitmen, tanggung jawab dan kewajiban pemerintah sekaligus hak setiap warga negara. Kondisi yang digambarkan tersebut menunjukkan adanya kesenjangan antara tuntutan dunia pendidikan yang seharusnya di satu pihak dengan kondisi yang sebenarnya terjadi pada tingkat layanan pendidikan dilain pihak. Kesenjangan ini akan lebih nampak apabila dicermati layanan pembelajaran untuk anak kebutuhan khusus (ABK) yang mencakup pembelajaran untuk anak tunagrahita.

Anak tunagrahita memerlukan layanan pembelajaran yang mengacu kepada kebutuhan yang khusus karena mempunyai kemampuan atau keterbatasan belajar dan adaptasi sosialnya berada di bawah rata-rata kemampuan anak pada umumnya. Oleh karena itu identifikasi terhadap keadaan anak tunagrahita dipandang perlu guna mengetahui keterbatasannya, dengan mengetahui keterbatasan anak tunagrahita, guru harus dapat melakukan tindakan pembelajaran yang sesuai dengan kebutuhan anak. Menurut Kosasih (2012, p.141) anak tunagrahita yaitu anak yang mempunyai kelainan karena penyimpangan, baik dari segi fisik, mental, intelektual, emosi, sikap maupun perilaku sosial secara signifikan. Hal itu disebabkan adanya kerusakan dalam jaringan susunan saraf pusat yang menyebabkan tidak berfungsinya susunan saraf itu sehingga proses kerjanya tidak berjalan dengan baik.

Pendidikan jasmani untuk anak tunagrahita memerlukan rancangan yang khusus agar kemampuan keterampilan motoriknya mengalami pertumbuhan dan perkembangan yang optimal. Pendidikan jasmani bagi anak tunagrahita harus disesuaikan dengan karakteristik dan kemampuannya, sehingga peserta didik dapat secara aktif mengikuti pembelajaran pendidikan jasmani di sekolah. Selain itu dengan rancangan yang diadaptasikan dengan kebutuhan peserta didik maka pendidikan jasmani bagi anak tunagrahita memberikan makna yang lebih mendalam tidak hanya bermakna sebagai materi pelajaran yang harus diikutinya dan tidak menjadi pelajaran yang sulit diikuti dan membosankan, tapi harus menjadi aktivitas yang menyenangkan.

Salah satu pembelajaran yang menarik untuk anak salah satunya dengan bermain, tidak terkecuali juga dengan anak tunagrahita. Melalui kegiatan bermain anak bisa mencapai perkembangan fisik, intelektual, emosi dan sosial. Perkembangan secara fisik dapat dilihat saat bermain. Perkembangan intelektual bisa dilihat dari kemampuannya mengunakan atau memanfaatkan lingkungannya. Perkembangan emosi dapat dilihat ketika anak merasa senang, marah, menang dan kalah. Perkembangan sosial bisa dilihat dari hubungannya dengan teman sebaya, menolong, antri dalam menunggu permainan dan memperhatikan kepentingan orang lain.

Seiring perkembangan zaman, jenis permainan yang ada pun semakin beragam. Ternyata permainan tradisional berpengaruh dan bermanfaat bagi perkembangan kemampuan motorik kasar anak seperti berjalan, berlari, melempar, menangkap, melompat, dan meloncat. Ini bisa dibuktikan dengan adanya gerakan-gerakan dalam permainan tradisional yang mengarah kepada keterampilan motorik kasar tersebut. Dengan demikian keterampilan motorik kasar sangat diperlukan bagi anak agar 
mampu melakukan aktivitas secara mandiri. Demikian juga dengan anak tunagrahita, anak tunagrahita sangat membutuhkan pengembangan kemampuan motorik kasar agar dapat berfungsi secara optimal.

Oleh karena itu, berdasarkan permasalahan tersebut penulis mencoba menyusun penelitian yang berjudul "Pengembangan Model Pembelajaran Berbasis Permainan Tradisional untuk Meningkatkan Kemampuan Motorik Kasar Anak Tunagrahita Ringan.”

Anak Tunagrahita Ringan

Menurut American Psychiatric Association (2013, p.33) anak tunagrahita atau disebut dengan IDD (Intellectual Developmental Disorder) atau gangguan perkembangan intelektual adalah anak yang mengalami gangguan pada masa periode perkembangan yang meliputi intelektual dan keterbatasan fungsi adaptif dalam konseptual, sosial, dan keterampilan adaptif, mempunyai IQ antara 68-52 menurut Skala Binet, sedangkan menurut Skala Weschler (WISC) memiliki IQ 69-55 (Somantri, 2012, p.106).

Karakteristik Anak Tunagrahita Ringan

Menurut Wantah (2007, p.10) bahwa anak yang tergolong retardasi mental ringan atau tunagrahita ringan, adalah anak yang hanya dapat mempelajari keterampilan dan tingkatan akademik sampai kelas 6 Sekolah Dasar (SD). Anak tunagrahita ringan memiliki kemampuan untuk berbicara, tetapi perbendaharaan kata-kata sangat kurang. Kurangnya perbendaharaan kata mengakibatkan anak tunagrahita ringan mengalami kesulitan untuk berpikir abstrak, tetapi anak tunagrahita ringan dapat mengikuti pendidikan baik di SD maupun di Sekolah Luar Biasa bagian C (SLB/C). Sebagai contoh, anak yang berumur 16 tahun, umur kecerdasan anak tersebut baru mencapai umur kecerdasan setingkat dengan anak yang berumur 12 tahun.

Karakteristik Motorik Anak Tunagrahita Ringan

Menurut Mumpuniarti (2007, p.17) bahwa karakteristik motorik anak tunagrahita ringan lebih rendah dari anak normal. Karakteristik fisik yang tidak jauh berbeda dengan anak normal ini yang menyebabkan tidak terdeteksi sejak awal sebelum masuk sekolah. Berikut disampaikan adaptasi dalam aktivitas fisik dan kegiatan jasmani anak normal dengan anak tunagrahita ringan (Auxter, Pyfer, Huettig, 2001, p.443).

Tabel 1. Adaptasi dalam Aktivitas Fisik dan Kegiatan Jasmani Anak Normal dengan Anak Tunagrahita Ringan

\begin{tabular}{|c|c|c|}
\hline $\begin{array}{l}\text { Usia } \\
\text { Kronologi }\end{array}$ & Aktivitas Jasmani Anak Normal & $\begin{array}{c}\text { Aktivitas Jasmani yang dapat Dilakukan Anak } \\
\text { Tunagrahita Ringan }\end{array}$ \\
\hline $\begin{array}{l}4 \text { sampai } 8 \\
\text { tahun }\end{array}$ & $\begin{array}{l}\text { Dapat melakukan aktivitas jasmani/gerak } \\
\text { dasar seperti berjalan, berlari, melompat, } \\
\text { meloncat sebagai rutinitas kegiatan } \\
\text { bermain tetapi belum terorganisir. }\end{array}$ & $\begin{array}{l}\text { Dalam tahap belajar dan mengalami kesulitan dalam } \\
\text { melakukan aktivitas jasmani/gerak dasar seperti } \\
\text { berlari, melompat, meloncat. }\end{array}$ \\
\hline $\begin{array}{l}8 \text { sampai } \\
12 \text { tahun }\end{array}$ & $\begin{array}{l}\text { Dapat bermain atau melakukan aktivitas } \\
\text { olahraga yang melibatkan memanipulasi } \\
\text { sebuah benda (melempar, menangkap). } \\
\text { Dapat bermain secara kompetisidan dapat } \\
\text { mengikuti peraturan permainan. }\end{array}$ & $\begin{array}{l}\text { Kurang dapat atau masih kesulitan melakukan } \\
\text { gerakan manipulasi sebuah benda (melempar, } \\
\text { menangkap). Dapat mengikuti aktivitas bermain } \\
\text { tetapi dengan arahan yang sederhana. }\end{array}$ \\
\hline $\begin{array}{l}12 \text { sampai } \\
17 \text { tahun }\end{array}$ & $\begin{array}{l}\text { Dapat bermain dengan organisasi yang } \\
\text { tinggi. Dapat mengembangkan } \\
\text { keterampilan olahraga yang menggunakan } \\
\text { raket dan bola. Dapat berpartisipasi dalam } \\
\text { permainan tim dengan menerapkan strategi } \\
\text { dalam kegiatan kompetitif. }\end{array}$ & $\begin{array}{l}\text { Dapat berpartisipasi dalam kegiatan olahraga yang } \\
\text { dimodifikasi. Lebih efektif dengan olahraga yang } \\
\text { mempunyai sifat individual, karena sedikit } \\
\text { tanggung jawab sosial. Dapat melakukan gerakan } \\
\text { manipulatif (melempar dan menangkap) tetapi sulit } \\
\text { untuk berpartisipasi dalam kegiatan kompetitif. }\end{array}$ \\
\hline $\begin{array}{l}\text { Lebih dari } \\
17 \text { tahun }\end{array}$ & $\begin{array}{l}\text { Dapat berpartisipasi secara mandiri dalam } \\
\text { kegiatan olahraga rekreasi di masyarakat } \\
\text { maupun di pendidikan yang dipilih. }\end{array}$ & $\begin{array}{l}\text { Dapat berpartisipasi dalam olahraga/aktivitas fisik } \\
\text { rekreasi di pendidikan maupun di masyarakat dalam } \\
\text { program-program khusus dan dengan melibatkan } \\
\text { bantuan orang lain. }\end{array}$ \\
\hline
\end{tabular}




\section{Bermain}

Bermain merupakan kegiatan yang spontan dilakukan oleh anak. Menurut Rosdiani (2012, p.114) bermain adalah aktivitas yang digunakan untuk mendapatkan kesenangan, keriangan atau kebahagiaan. Maksudnya tidak ada peraturan yang mengikat atau membutuhkan syarat-syarat tertentu. Bermain merupakan sesuatu hal yang sangat penting yang dapat mempengaruhi kognitif anak-anak, fisik, emosional, pembangunan sosial, dan menyediakan tempat utama untuk partisipasi sosial (Behr, Rodger, Mickan, 2013, p.198).

\section{Karakteristik Bermain}

Bermain mempunyai karakteristik yang sangat esensial. Menurut Hughes (2010, p.4) karakteristik dari bermain yaitu, (1) bermain didorong oleh motivasi intrinsik, maksudnya yang mendorong anak untuk melakukan kegiatan bermain tersebut adalah kegiatannya itu sendiri, bukan faktor-faktor luar yang bersifat ekstrinsik. Misalnya dorongan dari orang tua, untuk mendapatkan hadiah,dan sebagainya; (2) bermain itu bersifat aktif dan bebas dapat diikuti oleh siapa saja, maksudnya bermain memerlukan keterlibatan aktif dari para pelakunya dan terbuka dapat diikuti oleh siapa saja tanpa ada paksaan dan anak yang bermain memiliki kebebasan untuk memilih jenis kegiatan yang ingin dilakukannya; (3) bermain itu menyenangkan, maksudnya bermain bisa memberikan perasaan-perasaan positif bagi pelakunya, artinya semakin aktivitas itu menyenangkan maka hal tersebut semakin merupakan bermain; (4) bermain lebih berorientasi pada proses bukan hasil yang sesungguhnya, maksudnya fokus dalam bermain adalah melakukan aktivitas bermain itu sendiri, bukan hasil atau akhir dari kegiatannya.

\section{Permainan Tradisional}

Menurut Ardiwinata, dkk (2006, p.1) olahraga tradisional merupakan warisan kebudayaan nenek moyang bangsa Indonesia. Olahraga tradisional harus memenuhi dua persyaratan yaitu berupa "olahraga" dan sekaligus juga "tradisional" baik dalam memiliki tradisi yang telah berkembang selama beberapa generasi, maupun dalam arti sesuatu yang terkait dengan tradisi budaya suatu bangsa secara lebih luas. Berat ringannya persyaratan teknik dari berbagai bentuk olahraga tradisional di Indonesia sangat bervariasi. Persyaratan teknik yang ada di dalam olahraga tradisional di antaranya adalah (1) kekuatan tubuh, (2) kelenturan tubuh, (3) kecepatan gerak, dan (4) kemampuan reaksi. Nilai-nilai budaya yang terkandung di dalam bentuk olahraga tradisional adalah penghargaan pada usaha yang keras untuk mencapai prestasi unggul, penghargaan pada prestasi orang lain, pesaing, ikatan kelompok religiusitas dan lainlain.

\section{Prinsip-prinsip Olahraga Tradisional}

Menurut Ardiwinata, dkk (2006, p.4) dalam olahraga tradisional perlu diperhatikan adanya pemilahan antara permainan anak-anak dengan permainan orang dewasa. Olahraga tradisional bagi orang dewasa termasuk dalam berbagai lomba seperti perang pandan, karapan sapi, sodoran, adu domba dan sebagainya. Sedangkan olahraga tradisional untuk anak-anak terdapat berbagai jenis tergantung dari berbagai suku bangsa yang memiliki olahraga tersebut lebih bersifat permainan. Pada dasarnya olahraga tradisional memiliki unsur keterampilan fisik, kecepatan berfikir, serta implementasinya terhadap nilai sosial dan budaya. Dijelaskan lebih lanjut mengenai komponen biomotor menurut Sukadiyanto (2011, p.60) yaitu (1) ketahanan, (2) kekuatan, (3) kecepatan, (4) fleksibilitas, dan (5) koordinasi.

\section{Keterampilan Motorik Kasar}

Menurut Lerner \& Kline (2006, p.233) keterampilan motorik kasar melibatkan kemampuan otot-otot besar, seperti leher, lengan, dan kaki. Keterampilan motorik kasar meliputi berjalan, berlari, menangkap, dan melompat. Untuk memberikan rangsangan untuk pengembangan motorik kasar, anak-anak membutuhkan lingkungan yang aman yang bebas dari rintangan, dan anak membutuhkan banyak dorongan dari orang tua dan guru.

\section{Gerak Dasar Motorik Kasar pada Anak}

Menurut Lumintuarso (2013, p.34) gerak dasar motorik kasar pada anak memacu kemampuan anak saat beraktivitas dengan menggunakan otot-otot besarnya. Gerak dasar motorik kasar seperti lokomotor, nonlokomotor dan manipulatif dapat dijelaskan sebagai berikut: (a) gerak lokomotor adalah aktivitas gerak memindahkan tubuh dari satu tempat ke tempat lain, seperti jalan, lari, lompat, skip, roll, lompat tendang kaki, leap; (b) gerak nonlokomotor adalah aktivitas gerak tanpa harus memindahkan tubuh ke tempat lain, seperti mengguncang 
(shake), mengayun, kontraksi, tekuk, memantul, twist, rebah; dan (c) gerak manipulatif adalah gerak memanipulasi benda, seperti melempar, menangkap, menendang, memukul.

\section{Pendidikan Jasmani Adaptif}

Pada dasarnya pembelajaran adaptif merupakan pembelajaran biasa yang dimodifikasi dan dirancang sedemikian rupa sehingga dapat dipelajari, dilaksanakan, dan diadaptasikan sesuai dengan karakteristik anak berkebutuhan khusus, termasuk di dalamnya yaitu pembelajaran pendidikan jasmani. Dengan pendidikan jasmani adaptif diharapkan anak yang mengalami kebutuhan khusus dapat mengikuti program-program pembelajaran yang akan diajarkan, sehingga akan mencapai tujuan pembelajaran yang diinginkan.

\section{Metode Penelitian}

\section{Jenis Penelitian}

Penelitian ini merupakan penelitian pengembangan (Research and Development). Menurut Borg \& Gall (2003, p.569) penelitian $\mathrm{R} \& \mathrm{D}$ adalah model pengembangan industri di mana penemuan dari penelitiannya digunakan untuk produk-produk dan aturan baru, kemudia dilakukan uji coba lapangan secara sistematis, terevaluasi, dan terstruktur sehingga peneliti menemukan kriteria yang terspesifikasi menurut kefektifan, kualitas, atau standar yang serupa.

Waktu dan Tempat Penelitian

Uji coba skala kecil dilaksanakan pada bulan Januari 2014 di SLB Tunas Kasih 2 Turi, Sleman dan uji coba skala besar dilaksanakan pada bulan Maret 2014 di SLB ABCD Tunas Kasih Donoharjo, Sleman.

Subjek Penelitian

Subjek coba dalam penelitian pengembangan ini adalah anak tunagrahita ringan. Uji coba skala kecil dilaksanakan di SLB Tunas Kasih 2 Turi, Sleman berjumlah 6 anak dan uji coba skala besar dilaksanakan di SLB ABCD Tunas Kasih Donoharjo, Sleman yang berjumlah 12 anak.

Prosedur Penelitian dan Pengembangan

Menurut Borg and Gall (1987, p.784) ada 10 tahap penelitian $R \& D$ adalah sebagai berikut:

\section{Studi Pendahuluan}

Peneliti melakukan kajian awal menganalisis kebutuhan, melakukan pengumpulan informasi lebih lanjut dengan melakukan studi pendahuluan baik dengan cara studi pustaka maupun wawancara langsung dengan guru. Hal yang dilakukan dalam studi pustaka yaitu dengan mengumpulkan bahan mengenai teoriteori, data, dan hasil penelitian yang terkait dengan penelitian ini

\section{Melakukan Analisis terhadap Informasi yang telah Dikumpulkan}

Pada tahap ini peneliti mulai menetapkan rancangan model untuk memecahkan masalah yang telah ditemukan pada tahap awal. Hal yang direncanakan antara lain: menetapkan model pembelajaran, merumuskan tujuan secara bertahap, mengidentifikasi kegiatan-kegiatan yang dilakukan pada setiap tahap penelitian

\section{Pengembangan Draf Awal}

Setelah menganalisis terhadap masalah yang dikumpulkan berdasarkan studi pendahuluan, kemudian dilanjutkan dengan mengembangkan model-model pembelajaran berbasis permainan tradisional dengan menyusun butirbutir instrumen berdasarkan indikator yang telah ditentukan dalam standart kompetensi dasar di dalam kurikulum SLB.

\section{Validasi Draf Awal}

Setelah penyusunan butir tes selesai, dilanjutkan dengan penilaian para ahli materi, yaitu (1) pakar bidang olahraga adaptif, dan (2) pakar bidang pendidikan jasmani. Kemudian dilanjutkan dengan penilaian dari para ahli media. Pada proses validasi, para ahli materi menilai dan memberi masukan terhadap produk awal. Berdasarkan hal tersebut, dilakukan revisi terhadap produk awal. Proses revisi ini terus dilakukan sampai produk awal mencapai batas nilai tertentu yang telah ditetapkan, yang menunjukkan bahwa produk awal tersebut valid dan layak diujicobakan.

\section{Uji Lapangan Skala Kecil}

Uji lapangan skala kecil dilakukan oleh siswa di SLB Tunas Kasih 2 Turi dan didokumentasikan dalam bentuk Digital Versatile Disc $(D V D)$. Digital Versatile Disc (DVD) ini berisikan pelaksanaan pembelajaran berbasis permainan tradisional yang kemudian diobservasi oleh para pakar beserta guru dan ditindaklanjuti dengan proses revisi produk. 
Revisi

Revisi produk yang dilakukan dari hasil uji coba skala kecil, dengan menganalisis kekurangan yang ditemui dalam uji coba skala kecil, masukan yang diterima dai para pakar ditindaklanjuti dengan melakukan revisi produk. Revisi hasil uji coba skala kecil diharapkan menjadi tambahan untuk menghadapi uji coba skala besar.

\section{Uji Lapangan Skala Besar}

Uji lapangan skala besar oleh siswa di SLB ABCD Tunas Kasih Donoharjo, dan didokumentasikan dalam bentuk Digital Versatile Disc (DVD). Digital Versatile Disc (DVD) ini berisikan pelaksanaan pembelajaran berbasis permainan tradisional yang kemudian diobservasi oleh para pakar dan ditindaklanjuti dengan proses revisi produk. Proses yang dilakukan pada tahap uji lapangan skala besar serupa dengan proses yang dilakukan pada tahap uji lapangan skala kecil. Hal yang membedakan terletak pada jumlah subjek uji lapangan skala besar yang lebih banyak dari pada uji lapangan skala kecil.

\section{Revisi Akhir}

Proses revisi produk dilakukan untuk mendapat masukan dari para ahli materi agar menghasilkan produk final, langkah ini merupakan penyempurnaan produk yang dikembangkan agar produk akhir lebih akurat. Pada tahap ini sudah didapatkan suatu produk berupa DVD pengembangan model pembelajaran berbasis permainan tradisional untuk meningkatkan kemampuan motorik kasar anak tunagrahita ringan.

\section{Pembuatan Produk Final}

Setelah melalui berbagai proses revisi, kemudian dilakukan penyusunan dari hasil pengembangan setelah melakukan uji lapangan skala kecil dan skala besar, yaitu pembuatan produk akhir atau produk final berupa buku panduan dan DVD pembelajaran model pembelajaran berbasis permainan tradisional untuk meningkatkan kemampuan motorik kasar anak tunagrahita ringan. Produk final ini yang nantinya akan dipergunakan.

\section{Diseminasi dan Implementasi Produk Final}

Desiminasi produk final yaitu melaporkan produk pada forum ilmiah dalam bentuk ujian tesis. Sedangkan implementasi produk final berupa jurnal yang diterbitkan.

\section{Desain Uji Coba}

Uji coba produk atau draf model dilakukan sebanyak dua kali, yaitu uji coba skala kecil dan uji coba skala besar. Sebelum dilaksanakan uji coba di lapangan (uji coba skala kecil dan besar), produk penelitian berupa draf model pembelajaran berbasis permainan tradisional untuk meningkatkan kemampuan motorik kasar anak tunagrahita ringan. Selanjutnya dimintakan validasi terlebih dahulu kepada para pakar yang telah ditunjuk, dalam tahap tersebut selain validasi para pakar juga akan diberikan penilaian terhadap draf model yang setelah disusun, sehingga akan diketahui apakah model yang disusun layak untuk diujicobakan di lapangan. Kemudian dalam tahap uji coba di lapangan peran dari para pakar adalah untuk mengobservasi kelayakan draf model yang telah disusun dengan kenyataan di lapangan. Setelah uji coba skala luas maka akan menghasilkan sebuah model yang benar-benar valid.

\section{Subjek Coba}

Subjek coba dalam penelitian ini adalah anak-anak tunagrahita ringan di SLB Tunas Kasih 2 Turi Sleman dan SLB ABCD Tunas Kasih Donoharjo. Sesuai dengan tahapan penelitian, maka akan dilaksanakan beberapa tahapan proses pengambilan data. Dalam penelitian ini dilakukan uji coba model di lapangan, yaitu uji coba skala kecil dan uji coba skala besar. Untuk uji coba skala kecil melibatkan 6 anak tunagrahita ringan dan uji coba skala besar melibatkan 12 anak tunagrahita ringan.

\section{Jenis Data}

Jenis data yang diperoleh dalam penelitian dan pengembangan ini yaitu data kualitatif dan data kuantitatif. Data kualitatif berasal dari: (a) hasil wawancara dengan guru SLB, (b) data kekurangan model pembelajaran permainan tradisional dari ahli materi dan guru pelaku uji coba, dan (c) data masukan ahli materi dan guru pelaku uji coba terhadap model pembelajaran berbasis permainan tradisional. Data kuantitatif diperoleh dari: (a) penilaian ahli materi terhadap model pembelajaran berbasis permainan tradisional, dan (b) penilaian guru terhadap keefektifan model pembelajaran berbasis permainan tradisional. 
Instrumen Pengumpulan Data

\section{Wawancara}

Menurut Riduwan (2011, p.74) menyatakan bahwa wawancara adalah suatu cara pengumpulan data yang digunakan untuk memperoleh informasi langsung dari sumbernya. Wawancara ini digunakan bila ingin mengetahui hal-hal dari responden secara lebih mendalam. Butir-butir pertanyaan tersebut meliputi: (1) pembelajaran permainan tradisional sudah sesuai dengan kurikulum, (2) seperti apa kegiatan yang diberikan dalam materi pembelajaran pendidikan jasmani, (3) lama waktu pembelajaran pendidikan jasmani, (4) sarana yang dimiliki SLB, (5) peralatan yang di gunakan di SLB, (6) kendala yang di alami saat pembelajaran pendidikan jasmani khususnya dalam mengembangkan keterampilan motorik kasar, (7) masalah yang dihadapi oleh peserta didik saat mengikuti pembelajaran pendidikan jasmani, (8) usaha-usaha yang dilakukan oleh guru SLB.

\section{Skala Nilai}

Instrumen pengumpul data kedua yang digunakan yaitu skala nilai. Skala nilai digunakan untuk menilai kelayakan model pembelajaran berbasis permainan tradisional yang dikembangkan sebelum pelaksanaan uji coba skala kecil, setelah para ahli menilai bahwa pembelajaran permainan tradisional sudah sesuai dengan unsur-unsur dalam skala nilai, model pembelajaran berbasis permainan tradisional baru dapat diuji cobakan dalam uji coba skala kecil. Terdapat sepuluh format penilaian untuk masing-masing permainan, berbeda dengan indikator tujuan permainan yang berbeda-beda di dalam setiap permainan. Sistem penilaian dalam format penialain terdiri dari empat kriteria penilaian yaitu anak dapat melakukan gerakan dengan benar mendapat skor 3, anak dapat melakukan gerakan sendiri tetapi belum sempurna mendapat skor 2, anak dapat melakukan gerakan dengan bantuan mendapatkan skor 1, dan anak tidak dapat melakukan gerakan mendapatkan skor 0 .

\section{Teknik Analisis Data}

Teknik analisis data yang digunakan dalam penelitian ini adalah analisis data deskriptif. Ada dua macam teknik analisis data deskriptif yang dilakukan, yang pertama yaitu analisis data deskriptif kuantitatif, analisis ini dilakukan untuk menganalisis data hasil obser- vasi para ahli pembelajaran penjas, ahli olahraga adaptif, guru dan ahli media terhadap kualitas draf model yang disusun dan dianalisis oleh para ahli sebelum pelaksanaan uji coba di lapangan. Analisis data yang kedua yaitu analisis data deskriptif kualitatif, analisis ini dilakukan terhadap data hasil observasi para ahli pembelajaran penjas, pakar olahraga adaptif, guru dan pakar media dalam memberikan saran ataupun masukan serta revisi terhadap model yang disusun terutama dalam tahap uji coba lapangan baik skala kecil maupun skala besar.

Draf permainan dianggap layak untuk diuji cobakan dalam skala kecil apabila ahli materi pembelajaran pendidikan jasmani, olahraga adaptif dan media telah memberi validasi dan menyatakan bahwa semua item klasifikasi dalam skala nilai dinilai "sesuai" dengan memberi tanda centang $(\sqrt{ })$ pada kolom sesuai. Dalam hal ini terdapat dua jenis nilai, yaitu hasil penilaian "sesuai" mendapat nilai satu (1) dan hasil penilaian "tidak sesuai" mendapat nilai nol (0). Jika terdapat para ahli materi berpendapat bahwa item klasifikasi tidak sesuai (nilai nol), maka dilakukan pengkajian ulang terhadap model permainan yang dapat ditindaklanjuti dengan proses revisi.

Untuk data hasil observasi para ahli materi terhadap model permainan, hasil observasi "ya" mendapat nilai satu (1) dan hasil observasi "tidak" mendapat nilai nol (0). Hasil penilaian terhadap item-item observasi dijumlahkan, lalu total nilainya dikonversikan untuk mengetahui berapa kategorinya. Pengkonversian nilai dilakukan dengan mengikuti standart Penilaian Acuan Patokan (PAP). Dalam menginterpretasikan skor mentah menjadi nilai dengan menggunakan pendekatan PAP, yang akan dipaparkan berikut ini (Nurhasan, 2001, p.282).

Tabel 2. Pedoman Konversi Nilai

\begin{tabular}{ccc}
\hline Skor Nilai & Kategori & Keterangan \\
\hline $81 \%-100 \%$ & A & Sangat Baik \\
$66 \%-79 \%$ & B & Baik \\
$56 \%-65 \%$ & C & Cukup \\
$41 \%-55 \%$ & D & Kurang \\
$0 \%-40 \%$ & E & Kurang Sekali \\
\hline
\end{tabular}

\section{Hasil Penelitian dan Pembahasan}

Penelitian ini terdapat 8 model yang dikembangkan antara lain: (1) balap sarung, (2) lempar karet (3) dorong ban, (4) engkling, (5) pukul balon, (6) layang-layang, (7) lompat tali, dan (8) pesawat terbang. 
Skala Kecil

\section{Balap Sarung}

Berdasarkan data hasil observasi permainan, menurut penilaian para ahli pembelajaran pendidikan jasmani, ahli olahraga adapted dan guru bahwa model pembelajaran berbasis permainan tradisional balap sarung menunjukkan rentang nilai $66 \%$ s.d $79 \%$ dari $70 \%$ termasuk dalam kategori $\mathrm{B}=$ baik. Kemudian berdasarkan lembar format penilaian efektifitas model, bahwa model pembelajaran berbasis permainan tradisional balap sarung menunjukkan rentang nilai $81 \%$ s.d $100 \%$ dari 97\% termasuk dalam kategori $\mathrm{A}=$ sangat baik.

\section{Lempar Karet}

Berdasarkan data hasil observasi permainan, menurut penilaian para ahli pembelajaran pendidikan jasmani, ahli olahraga adapted dan guru bahwa model pembelajaran berbasis permainan tradisional lempar karet menunjukkan rentang nilai $66 \%$ s.d $79 \%$ dari $68 \%$ termasuk dalam kategori $\mathrm{B}=$ baik. Kemudian berdasarkan lembar format penilaian efektifitas model, bahwa model pembelajaran berbasis permainan tradisional lempar karet menunjukkan rentang nilai $81 \%$ s.d $100 \%$ dari $97 \%$ termasuk dalam kategori $\mathrm{A}=$ sangat baik.

\section{Dorong Ban}

Berdasarkan data hasil observasi permainan, menurut penilaian para ahli pembelajaran pendidikan jasmani, ahli olahraga adapted dan guru bahwa model pembelajaran berbasis permainan tradisional dorong ban menunjukkan rentang nilai $66 \%$ s.d $79 \%$ dari $78 \%$ termasuk dalam kategori $\mathrm{B}=$ baik. Kemudian berdasarkan lembar format penilaian efektifitas model, bahwa model pembelajaran berbasis permainan tradisional dorong ban menunjukkan rentang nilai $81 \%$ s.d $100 \%$ dari $96 \%$ termasuk dalam kategori $\mathrm{A}=$ sangat baik.

\section{Engkling}

Berdasarkan data hasil observasi permainan, menurut penilaian para ahli pembelajaran pendidikan jasmani, ahli olahraga adapted dan guru bahwa model pembelajaran berbasis permainan tradisional engkling menunjukkan rentang nilai $56 \%$ s.d $65 \%$ dari $78 \%$ termasuk dalam kategori $\mathrm{C}=$ cukup. Kemudian berdasarkan lembar format penilaian efektifitas model, bahwa model pembelajaran berbasis permainan tradisional engkling menunjukkan rentang nilai $81 \%$ s.d $100 \%$ dari $96 \%$ termasuk dalam kategori $\mathrm{A}=$ sangat baik.

\section{Pukul Balon}

Berdasarkan data hasil observasi permainan, menurut penilaian para ahli pembelajaran pendidikan jasmani, ahli olahraga adapted dan guru bahwa model pembelajaran berbasis permainan tradisional pukul balon menunjukkan rentang nilai $66 \%$ s.d $79 \%$ dari $70 \%$ termasuk dalam kategori $\mathrm{B}=$ baik. Kemudian berdasarkan lembar format penilaian efektifitas model, bahwa model pembelajaran berbasis permainan tradisional pukul balon menunjukkan rentang nilai $81 \%$ s.d $100 \%$ dari 99\% termasuk dalam kategori $\mathrm{A}=$ sangat baik.

\section{Layang-layang}

Berdasarkan data hasil observasi permainan, menurut penilaian para ahli pembelajaran pendidikan jasmani, ahli olahraga adapted dan guru bahwa model pembelajaran berbasis permainan tradisional layang-layang menunjukkan rentang nilai $66 \%$ s.d $79 \%$ dari $73 \%$ termasuk dalam kategori $\mathrm{B}=$ baik. Kemudian berdasarkan lembar format penilaian efektifitas model, bahwa model pembelajaran berbasis permainan tradisional layang-layang menunjukkan rentang nilai $81 \%$ s.d $100 \%$ dari 95\% termasuk dalam kategori $\mathrm{A}=$ sangat baik.

\section{Lompat Tali}

Berdasarkan data hasil observasi permainan, menurut penilaian para ahli pembelajaran pendidikan jasmani, ahli olahraga adapted dan guru bahwa model pembelajaran berbasis permainan tradisional lompat tali menunjukkan rentang nilai $66 \%$ s.d $79 \%$ dari $73 \%$ termasuk dalam kategori $\mathrm{B}=$ baik. Kemudian berdasarkan lembar format penilaian efektifitas model, bahwa model pembelajaran berbasis permainan tradisional lompat tali menunjukkan rentang nilai $81 \%$ s.d $100 \%$ dari $93 \%$ termasuk dalam kategori $\mathrm{A}=$ sangat baik.

\section{Pesawat Terbang}

Berdasarkan data hasil observasi permainan, menurut penilaian para ahli pembelajaran pendidikan jasmani, ahli olahraga adapted dan guru bahwa model pembelajaran berbasis permainan tradisional pesawat terbang menunjukkan rentang nilai $66 \%$ s.d $79 \%$ dari $75 \%$ termasuk dalam kategori $\mathrm{B}=$ baik. Kemudian berdasarkan lembar format penilaian efektifitas model, bahwa model pembelajaran 
berbasis permainan tradisional pesawat terbang menunjukkan rentang nilai $81 \%$ s.d $100 \%$ dari 97\% termasuk dalam kategori $\mathrm{A}=$ sangat baik.

\section{Skala Besar}

\section{Balap Sarung}

Berdasarkan data hasil observasi permainan, menurut penilaian para ahli pembelajaran pendidikan jasmani, ahli olahraga adapted, ahli media dan guru bahwa model pembelajaran berbasis permainan tradisional balap sarung menunjukkan rentang nilai $81 \%$ s.d $100 \%$ dari $98 \%$ termasuk dalam kategori $\mathrm{A}=$ sangat baik. Kemudian berdasarkan lembar format penilaian efektifitas model, bahwa model pembelajaran berbasis permainan tradisional balap sarung menunjukkan rentang nilai $81 \%$ s.d $100 \%$ dari $99 \%$ termasuk dalam kategori $\mathrm{A}=$ sangat baik. Maka dapat disimpulkan bahwa model pembelajaran berbasis permainan tradisional balap sarung efektif dan layak digunakan untuk pembelajaran pendidikan jasmani bagi anak tunagrahita ringan.

\section{Lempar Karet}

Berdasarkan data hasil observasi permainan, menurut penilaian para ahli pembelajaran pendidikan jasmani, ahli olahraga adapted, ahli media dan guru bahwa model pembelajaran berbasis permainan tradisional lempar karet menunjukkan rentang nilai $81 \%$ s.d $100 \%$ dari $96 \%$ termasuk dalam kategori $\mathrm{A}=$ sangat baik. Kemudian berdasarkan lembar format penilaian efektifitas model, bahwa model pembelajaran berbasis permainan tradisional lempar karet menunjukkan rentang nilai $81 \%$ s.d $100 \%$ dari $99 \%$ termasuk dalam kategori $\mathrm{A}=$ sangat baik. Maka dapat disimpulkan bahwa model pembelajaran berbasis permainan tradisional lempar karet efektif dan layak digunakan untuk pembelajaran pendidikan jasmani bagi anak tunagrahita ringan.

\section{Dorong Ban}

Berdasarkan data hasil observasi permainan, menurut penilaian para ahli pembelajaran pendidikan jasmani, ahli olahraga adapted, ahli media dan guru bahwa model pembelajaran berbasis permainan tradisional dorong ban menunjukkan rentang nilai $81 \%$ s.d $100 \%$ dari $100 \%$ termasuk dalam kategori $\mathrm{A}=$ sangat baik. Kemudian berdasarkan lembar format penilaian efektifitas model, bahwa model pembelajaran berbasis permainan tradisional dorong ban menunjukkan rentang nilai $81 \%$ s.d
$100 \%$ dari $98 \%$ termasuk dalam kategori $\mathrm{A}=$ sangat baik. Maka dapat disimpulkan bahwa model pembelajaran berbasis permainan tradisional dorong ban efektif dan layak digunakan untuk pembelajaran pendidikan jasmani bagi anak tunagrahita ringan.

\section{Engkling}

Berdasarkan data hasil observasi permainan, menurut penilaian para ahli pembelajaran pendidikan jasmani, ahli olahraga adapted, ahli media dan guru bahwa model pembelajaran berbasis permainan tradisional engkling menunjukkan rentang nilai $81 \%$ sd $100 \%$ dari $94 \%$ termasuk dalam kategori $\mathrm{A}=$ sangat baik. Kemudian berdasarkan lembar format penilaian efektifitas model, bahwa model pembelajaran berbasis permainan tradisional engkling menunjukkan rentang nilai $81 \%$ s.d $100 \%$ dari $97 \%$ termasuk dalam kategori $\mathrm{A}=$ sangat baik. Maka dapat disimpulkan bahwa model pembelajaran berbasis permainan tradisional engkling efektif dan layak digunakan untuk pembelajaran pendidikan jasmani bagi anak tunagrahita ringan.

\section{Pukul Balon}

Berdasarkan data hasil observasi permainan, menurut penilaian para ahli pembelajaran pendidikan jasmani, ahli olahraga adapted, ahli media dan guru bahwa model pembelajaran berbasis permainan tradisional pukul balon menunjukkan rentang nilai $81 \%$ s.d $100 \%$ dari $98 \%$ termasuk dalam kategori $\mathrm{A}=$ sangat baik. Kemudian berdasarkan lembar format penilaian efektifitas model, bahwa model pembelajaran berbasis permainan tradisional pukul balon menunjukkan rentang nilai $81 \%$ s.d $100 \%$ dari $100 \%$ termasuk dalam kategori $\mathrm{A}=$ sangat baik. Maka dapat disimpulkan bahwa model pembelajaran berbasis permainan tradisional pukul balon efektif dan layak digunakan untuk pembelajaran pendidikan jasmani bagi anak tunagrahita ringan.

Layang-layang

Berdasarkan data hasil observasi permainan, menurut penilaian para ahli pembelajaran pendidikan jasmani, ahli olahraga adapted, ahli media dan guru bahwa model pembelajaran berbasis permainan tradisional layang-layang menunjukkan rentang nilai $81 \%$ s.d $100 \%$ dari $100 \%$ termasuk dalam kategori $\mathrm{A}=$ sangat baik. Kemudian berdasarkan lembar format penilaian efektifitas model, bahwa mo- 
del pembelajaran berbasis permainan tradisional layang-layang menunjukkan rentang nilai $81 \%$ s.d $100 \%$ dari $100 \%$ termasuk dalam kategori $\mathrm{A}=$ sangat baik. Maka dapat disimpulkan bahwa model pembelajaran berbasis permainan tradisional layang-layang efektif dan layak digunakan untuk pembelajaran pendidikan jasmani bagi anak tunagrahita ringan.

Lompat Tali

Berdasarkan data hasil observasi permainan, menurut penilaian para ahli pembelajaran pendidikan jasmani, ahli olahraga adapted, ahli media dan guru bahwa model pembelajaran berbasis permainan tradisional lompat tali menunjukkan rentang nilai $81 \%$ s.d $100 \%$ dari $96 \%$ termasuk dalam kategori $\mathrm{A}=$ sangat baik. Kemudian berdasarkan lembar format penilaian efektifitas model, bahwa model pembelajaran berbasis permainan tradisional lompat tali menunjukkan rentang nilai $81 \%$ s.d $100 \%$ dari $99 \%$ termasuk dalam kategori $\mathrm{A}=$ sangat baik. Maka dapat disimpulkan bahwa model pembelajaran berbasis permainan tradisional lompat tali efektif dan layak digunakan untuk pembelajaran pendidikan jasmani bagi anak tunagrahita ringan.

\section{Pesawat Terbang}

Berdasarkan data hasil observasi permainan, menurut penilaian para ahli pembelajaran pendidikan jasmani, ahli olahraga adapted, ahli media dan guru bahwa model pembelajaran berbasis permainan tradisional pesawat terbang menunjukkan rentang nilai $81 \%$ s.d $100 \%$ dari $100 \%$ termasuk dalam kategori $\mathrm{A}=$ sangat baik. Kemudian berdasarkan lembar format penilaian efektifitas model, bahwa model pembelajaran berbasis permainan tradisional pesawat terbang menunjukkan rentang nilai $81 \%$ s.d $100 \%$ dari $100 \%$ termasuk dalam kategori $\mathrm{A}=$ sangat baik. Maka dapat disimpulkan bahwa model pembelajaran berbasis permainan tradisional pesawat terbang efektif dan layak digunakan untuk pembelajaran pendidikan jasmani bagi anak tunagrahita ringan.

\section{Simpulan dan Saran}

\section{Simpulan}

Dari hasil penilaian para ahli materi dan guru terhadap model pembelajaran yang dikembangkan dapat disimpulkan bahwa model pembelajaran berbasis permainan tradisional untuk meningkatkan kemampuan motorik kasar anak tunagrahita ringan ini sangat baik dan efektif. Oleh karena itu, model pembelajaran yang dikembangkan ini layak untuk digunakan dan diterapkan dalam pembelajaran pendidikan jasmani untuk anak tunagrahita ringan.

Produk dari penelitian pengembangan ini yaitu buku panduan dan DVD pembelajaran berbasis permainan tradisional untuk meningkatkan kemampuan motorik kasar anak tunagrahita ringan, yang terdiri dari 8 model permainan, yaitu: (1) balap sarung, (2) lempar karet, (3) dorong ban, (4) engkling, (5) pukul balon, (6) layang-layang, (7) lompat tali, dan (8) pesawat terbang.

Saran

\section{Saran Pemanfaatan}

Saran pemanfaatan berdasarkan penelitian pengembangan yaitu agar model pembelajaran berbasis permainan tradisional yang dikembangkan dapat digunakan guru sebagai salah satu bentuk pembelajaran motorik kasar pada anak tunagrahita ringan, untuk dapat mewujudkan hal tersebut perlu ditingkatkan kemauan dan kesediaan guru untuk senantiasa meningkatkan kualitas pembelajaran dengan berbagai bentuk pembelajaran yang dapat meningkatkan minat dan kualitas peserta didik dalam belajar, meskipun hal tersebut berarti menambah kesibukan guru dalam menyiapkan bahan-bahan pembelajaran.

\section{Diseminasi}

Diseminasi hasil penelitian pengembangan ini dapat dilakukan melalui seminarseminar, pembuatan artikel, atau dapat juga dilakukan melalui penelitian tindakan kelas dengan melibatkan guru SLB untuk mengetahui efek nyata dari produk pengembangan model pembelajaran berbasis permainan tradisional.

\section{Pengembangan Produk Lebih Lanjut}

Untuk pengembangan produk lebih lanjut perlu dilakukan penelitian yang melibatkan subjek coba lebih besar dan cakupan tempat uji coba yang lebih luas.

\section{Daftar Pustaka}

Ardiwinata A.A, Suherman, \& Dinata, M. (2006). Kumpulan permainan rakyat olahraga tradisional. Tangerang: Penerbit Cerdas Jaya.

Association, A. P. (2013). Diagnostic and statistical manual of mental disorder 
fitth edition. Washington,
American Psychiatric Publising.

Auxter, D., Pyfer, J., \& Huettig, C. (2001). Principles and methods of adapted physical education and recreation ninth edition. New York: Mc Graw-Hill.

Behr, A. K, Rodger, S., \& Mickan, S. (2013). A comparison of the play skills of preschool children with and without developmental coordination disorder. American Occupational Therapy Foundation, 33, 198-208.

Borg, W.R., Gall, J.P., \& Gall, M.D. (2003). Educational research an introduction, seventh edition. New York: Longman.

Hughes, F.P. (2010). Children, play, and development, ( $4^{\text {th }}$ edition). USA: Sage Publications.

Kosasih, E. (2012). Cara bijak memahami anak berkebutuhan khusus. Bandung: Yrama Widya.

Lerner, J.W \& Kline, F. (2006). Learning disabilities and related disorders characteristics and teaching strategies, tenth edition. New York: Houghton Mifflin Company.

Lumintuarso, R. (2013). Pembinaan multilateral bagi atlet pemula pedoman latihan dasar bagi atlet muda berbakat. Yogyakarta: UNY Press.

Mumpuniarti. (2007). Pembelajaran akademik bagi tunagrahita. Yogyakarta: FIPUNY.

Nurhasan. (2001). Tes dan pengukuran dalam pendidikan jasmani: prinsip-prinsip dan penerapannya. Jakarta: Departemen Pendidikan Nasional.

Riduwan. (2011). Belajar mudah penelitian untuk guru-karyawan dan peneliti pemula. Bandung: Alfabeta.

Rosdiani, D. (2012). Dinamika olahraga dan pengembangan nilai. Bandung: Alfabeta.

Somantri, S. (2012). Psikologi anak luar biasa, cetakan ke 4. Bandung: Refika Aditama.

Sukadiyanto \& Muluk, D. (2011). Pengantar teori dan metodologi melatih fisik. Bandung: CV. Lubuk Agung.

Wantah, M.J. (2007). Pengembangan kemandirian anak tunagrahita mampu latih. Jakarta: Depdiknas. 